\title{
First record of parasites of Dosidicus gigas (d' Orbigny, 1835) (Cephalopoda: Ommastrephidae) from the Humboldt Current system off Chile
}

\author{
Primer registro de los parásitos de Dosidicus gigas (d’ Orbigny, 1835) (Cephalopoda: Ommastrephidae) \\ en el sistema de corriente de Humboldt frente a Chile
M. Cecilia Pardo-Gandarillas ${ }^{1}$, Karin B. Lohrmann², Ana L. Valdivia² and Christian M. Ibáñez ${ }^{1}$ \\ ${ }^{1}$ Instituto de Ecología y Biodiversidad, Departamento de Ciencias Ecológicas, Facultad de Ciencias, Universidad de Chile, \\ Las Palmeras 3425, Ñuñoa, Santiago, Chile \\ ${ }^{2}$ Facultad de Ciencias del Mar, Universidad Católica del Norte, Larrondo 1281, Coquimbo, Chile \\ pardogandarillas@gmail.com
}

\begin{abstract}
Resumen.- Se describió y cuantificó la fauna parasitaria de 124 calamares (Dosidicus gigas) capturados en aguas oceánicas y costeras en Chile Central $\left(32^{\circ} \mathrm{S}-40^{\circ} \mathrm{S}\right)$. El $97 \%$ de los calamares presentó al menos un taxón parásito. Se determinó la prevalencia y abundancia para cada especie de parásito. Cada taxón parasitario se describió en base a microscopía de luz e imágenes de microscopía electrónica de barrido. La fauna parasitaria estuvo compuesta por céstodos larvales: Hepatoxylon trichiuri (Abundancia: 2,6; Prevalencia: 70,2\%), Tentacularia coryphaenae (Abundancia: 0,1; Prevalencia: 5,6\%), plerocercoide Tetraphyllidea (Abundancia: 9,1; Prevalencia: 83,1\%), Pelichnibothrium speciosum y los nemátodos Anisakis Tipo I (Abundancia: 0,06; Prevalencia: 6,5\%) y Tipo II (Abundancia: 0,52; Prevalencia: 17,7\%). Se han descrito alrededor de 9 taxa parasitarios en $D$. gigas, todos encontrados en calamares menores a $40 \mathrm{~cm}$ de longitud del manto, y de los cuales cinco (plerocercoide Tetraphyllidea, Tentacularia coryphaenae Pelichnibothrium speciosum y Anisakis Tipo I y II), se registraron en este estudio, pero en calamares de mayor tamaño. El parásito $H$. trichiuri es un nuevo registro para $D$. gigas en estas latitudes del Pacífico Sur, comprendiendo el límite sur de su rango de distribución. El plerocercoide Tetraphyllidea, por tener un órgano apical con la misma forma y tejido celular que una ventosa accesoria, podría pertenecer al género Phyllobothrium. Los Anisakis Tipo I y II, sólo se pueden distinguir por la forma de la cola y la presencia-ausencia del mucrón. Se sugiere la realización de análisis moleculares cuando hay carencia de caracteres morfológicos de diagnósticos en los estados larvales.
\end{abstract}

Palabras clave: Calamar de Humboldt, fauna parasitaria, Pacífico suroriental

\begin{abstract}
The parasitic fauna of 124 jumbo squids (Dosidicus gigas) caught from oceanic and coastal waters off Central Chile $\left(32^{\circ} \mathrm{S}-40^{\circ} \mathrm{S}\right)$ was described and quantified. The $97 \%$ of the squids harboured at least one parasitic taxon. Prevalence of infection and abundance were established for each parasite species. Each parasitic taxon was described based on light microscopy and scanning electron microscopy images. The parasitic fauna was composed of larval cestodes: Hepatoxylon trichiuri (Abundance: 2.6; Prevalence: 70.2\%), Tentacularia coryphaenae (Abundance: 0.1; Prevalence: 5.6\%), a Tetraphyllidean plerocercoid (Abundance: 9.1; Prevalence: 83.1\%), Pelichnibothrium speciosum and the nematodes Anisakis Type I (Abundance: 0.06; Prevalence: 6.5\%) and Anisakis Type II (Abundance: 0.52; Prevalence: 17.7\%). Around nine taxa have been reported in D. gigas smaller than $40 \mathrm{~cm}$ mantle length, five of them were found in this study (Tetraphyllidean plerocercoid, Tentacularia coryphaenae, Pelichnibothrium speciosum, and Anisakis Type I and II), however, in bigger squids. The parasite $H$. trichiuri is a new record for $D$. gigas in these latitudes of the South Pacific, comprising the southern limit of its distribution range. The Tetraphyllidea plerocercoid could correspond to Phyllobothrium based on the shape and tissues of its apical organ, which is very similar to the accesory suckers. The nematodes Anisakis Type I and II can only be distinguished by the tail shape and presenceabsence of a mucron. It is suggested to carry out molecular analysis for diagnosis of larval stages when morphological characters are lacking.
\end{abstract}

Key words: Jumbo squid, helminth fauna, southeastern Pacific 


\section{Introduction}

The jumbo squid, Dosidicus gigas (d' Orbigny, 1835), is the most abundant squid of the Pacific Ocean (Nigmatullin et al. 2001, Keyl et al. 2008), and the largest marine invertebrate of the Chilean fauna (Schmiede \& Acuña 1992, Fernández \& Vásquez 1995). The geographic distribution of $D$. gigas extends from approximately $40^{\circ} \mathrm{N}$ to $42^{\circ} \mathrm{S}$ in the eastern Pacific Ocean, and lives both in oceanic as well as neritic water, from surface waters down to depths of $1200 \mathrm{~m}$ (Nigmatullin et al. 2001, Keyl et al. 2008). For D. gigas, three groups (small, medium, large) have been distinguished based on the size at maturity (Nigmatullin et al. 2001). The helminth fauna of medium sized D. gigas (300-431 mm mantle length) from Nicaraguan, Equatorial and Peruvian waters $\left(11^{\circ} \mathrm{N}-22^{\circ} \mathrm{S}\right)$, has been reported to be composed of larval stages of Didymozoidae, the cestoda Pelichnibothrium speciosum, Phyllobothrium sp., Tentacularia coryphaenae, and the nematodes Anisakis simplex, A. physeteris, Porrocaecum sp., Contracaecum sp., and Spinitectus sp. (Shukhgalter \& Nigmatullin 2001). However, Nigmatullin et al. (2005) also studied helminth fauna in five specimens of large mantle length (545-995 mm) D. gigas (area 7-9 ${ }^{\circ} \mathrm{S}$ and $83^{\circ} 30^{\prime}-84^{\circ} \mathrm{W}$ ), finding four helminth species: Pelichnibothrium speciosum, Tentacularia coryphaenae, Anisakis physeteris, Porrocaecum sp. (Nigmatullin et al. 2005'). Towards the South Pacific, only Bothriotaenia sp. has been registered for $D$. gigas from Chile ( $36^{\circ} 35^{\prime} \mathrm{S}$, Talcahuano) by Wilhelm (1954); there is no recent record of this parasite in these latitudes. This squid is considered as a paratenic host for the larval parasites that infect it, and the definitive hosts are fish, sharks and marine mammals (Shukhgalter \& Nigmatullin 2001).

The existence of unstable anatomical and meristic characters (e.g. in coccidians), cryptic species (e.g. in anisakid nematodes) or morphotypes (e.g. in cestodes) present particular difficulties for the identification because of the plasticity of body structures in most of the 200 endoparasitic species reported in cephalopods (Hochberg 1990, Pascual et al. 2007). In fact, most of these parasites have not been taxonomically identified to species level, with high rates of synonymy (close to 70\%) for numerous nominal parasite species or larval stages identified by light microscopy (Pascual et al. 2007).

\footnotetext{
${ }^{1}$ Nigmatullin CM, AS Shchetinnikov \& OA Shukhgalter. 2005. Food and parasite relations and role of the dominant ommastrephid squids in oceanic ecosystems of southeast Pacific in 1980-1985. Third International Symposium on Pacific squids. Lima, Peru, 28-30 November, 2005.
}

The use of scanning electron microscopy (SEM) has allowed the study of morphoanatomic and morphometric characteristics of the surface structures of many parasitic taxa, including some larvae of nematode and cestode species from cephalopods (Abollo et al. 1998, Gestal et al. 1998a, b, Pascual et al. 1999).

The aim of this study was to report a quantitative characterization and to describe the morphology of the helminth fauna of $D$. gigas from oceanic and coastal waters off central-southern Chile. Moreover, the results in this preliminary study of parasites in $D$. gigas from central and southern Pacific Ocean waters provided an opportunity to compare its helminth fauna with those previously reported from other latitudes in the Pacific Ocean. The differences in the helminth fauna may indicate a potential use for stock identification.

\section{Material and methods}

From July 2003 to February 2004, 51 samples of D. gigas were collected from the by-catch obtained by purse-seine fishing for jack mackerel, Trachurus murphyi in oceanic waters off central-southern Chile $\left(32^{\circ} \mathrm{S}-40^{\circ} \mathrm{S}\right)$ at depths between 10 and $70 \mathrm{~m}$. In addition, 73 samples were obtained from trawlers fishing for Chilean hake, Merluccius gayi, and Patagonian grenadier, Macruronus magellanicus, on the continental shelf of central-southern Chile $\left(34^{\circ} \mathrm{S}-40^{\circ} \mathrm{S}\right)$ near bottom at depths between 120 and $405 \mathrm{~m}$ (see Ibáñez et al. 2008, Fig. 1). The mantle length (ML, $\mathrm{cm}$ ) of each squid was measured and was $61.1 \mathrm{~cm}$ in average (range $=30-92 \mathrm{~cm}, \mathrm{SD}=16.5 \mathrm{~cm}$ ). The mantle cavity, muscle fibres, digestive tract, gonads, gills, digestive gland and other viscera were examined under a stereoscopic microscope, searching for endoparasites.

The methodology used for obtaining the parasites followed Pardo-Gandarillas et al. (2004). The nomenclature of Nematoda follows Yamaguti (1961), Hochberg (1990) and Shukhgalter \& Nigmatullin (2001), and for Cestoda it follows Williams (1968), Stunkard (1977), Hochberg (1990), Schmidt (1986), Scholtz et al. (1998), Shukhgalter \& Nigmatullin (2001) and Palm (2004). Demographic features were expressed in terms of prevalence and abundance (total number of parasitic individuals for a parasitic taxon / total number examined hosts; Margolis et al. 1982).

All parasites obtained were fixed in $10 \%$ formalin. Some nematodes were cleared in a mixture of glycerine, lactic acid, phenol and distilled water (lactophenol). Morphometric measures of 10-20 individuals of each parasite species were made, following Shukhgalter \& Nigmatullin (2001) and Palm (2004). The internal 
anatomy of each parasite species was drawn under a stereoscopic or light microscope. This material was deposited in the collection of molluscs parasites of Museo Nacional de Historia Natural de Chile (MNHNCL).

For SEM analyses the parasites were fixed in either $10 \%$ formalin in seawater (SW) or $2 \%$ glutaraldehyde in SW with 0.025M sodium cacodylate (Turner \& Boyle 1975). They were dehydrated in an ethanol series, critical point dried, and ion sputtered with gold.

Additionally, six large squids (80-88 cm ML) Coquimbo (295' $\mathrm{S}, 7^{\circ}{ }^{\circ} 36^{\prime} \mathrm{W}$ ) were examined in December 2008. In these specimens histology of the rectum was performed for cysts with merocercoids to be observed. Plerocercoids of Tetraphyllidean larvae were collected from the caecum, and along with small pieces of rectum, fixed in Davidson's fluid for $24 \mathrm{~h}$, transferred to $70 \%$ ethanol, and further processed for histology (Shaw \& Battle 1957). Five micrometer thick sections were cut from the rectum pieces, and from the plerocercoids longitudinal and transverse 6 $\mu \mathrm{m}$ thick sections of the scolex were cut. Photographs were taken from a Zeiss Axiostar Plus microscope with a Cannon Powershot A 620 camera.

\section{Results}

Of the 124 specimens of $D$. gigas examined, $96.7 \%$ were infected with at least one of the six taxa identified in this study.

\section{Cestoda}

Order: Trypanorhyncha Diesing, 1863

Family: Sphyriocephalidae Pintner, 1913

Genus: Hepatoxylon Bosc, 1811

Hepatoxylon trichiuri (Holten, 1802): (Abundance: 2.6; Prevalence: 70.2\%) (Figs. 1a, 2)

Description: Measurements based on 20 specimens. Size range 13-27 mm. Scolex large and muscular (length = 4$8 \mathrm{~mm}$, maximum width $=4-5 \mathrm{~mm}$, Fig. 1a). Two bothria large oval to elongated (length $=2-4 \mathrm{~mm}$ ) separated by narrow partition (Figs. 2a,b). Four tentacles short, globular or truncated (length $=0.6-0.78 \mathrm{~mm}$, maximum width $=0.57-0.71 \mathrm{~mm}$ ) (Fig. 2a). Metabasal armature homeoacanthous homeomorphous; hooks in 12-14 rows slender uncinate with anterior extension of the base
A

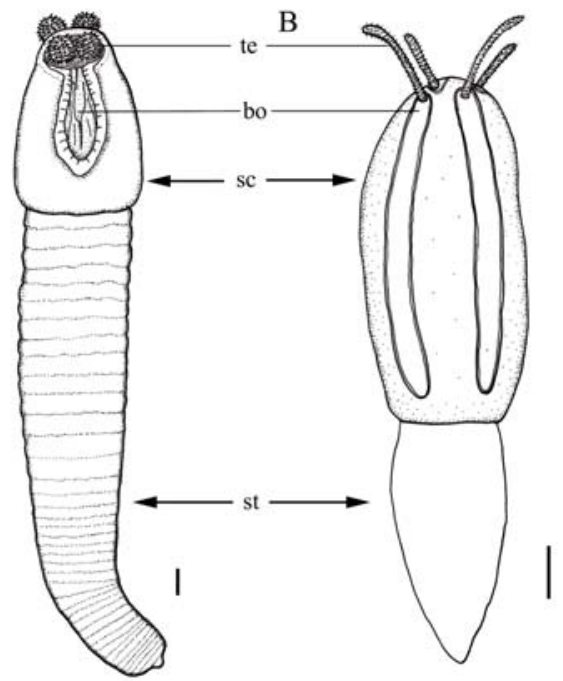

$\mathrm{C}$

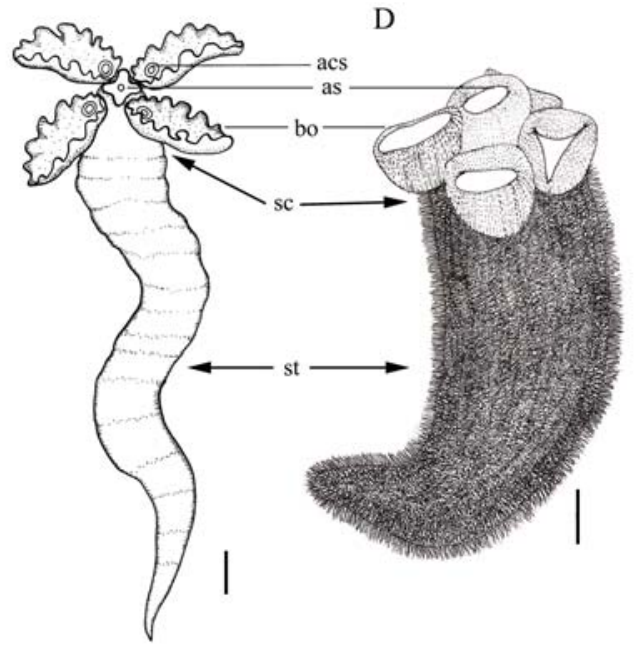

Figure 1

Cestode parasites of $\boldsymbol{D}$. gigas. A) Hepatoxylon trichiuri, B) Tentacularia coryphaenae, C) Tetraphyllidea plerocercoid D) Pelichnibothrium speciosum. Scale bar $1 \mathrm{~mm}$, except D $0.1 \mathrm{~mm}$. sc = scolex, bo = bothria, te $=$ tentacle, st $=$ strobila, as $=$ apical sucker, acs $=$ accessory sucker

Parásitos céstodos de D. gigas. A) Hepatoxylon trichiuri, B) Tentacularia coryphaenae, C) Plerocercoide Tetraphyllidea

D) Pelichnibothrium speciosum. Barra $1 \mathrm{~mm}$, excepto D 0,1 mm. sc = scolex, bo = botria, te $=$ tentáculo, $\mathrm{st}=$ estróbila, as = ventosa apical, acs = ventosa accesoria 


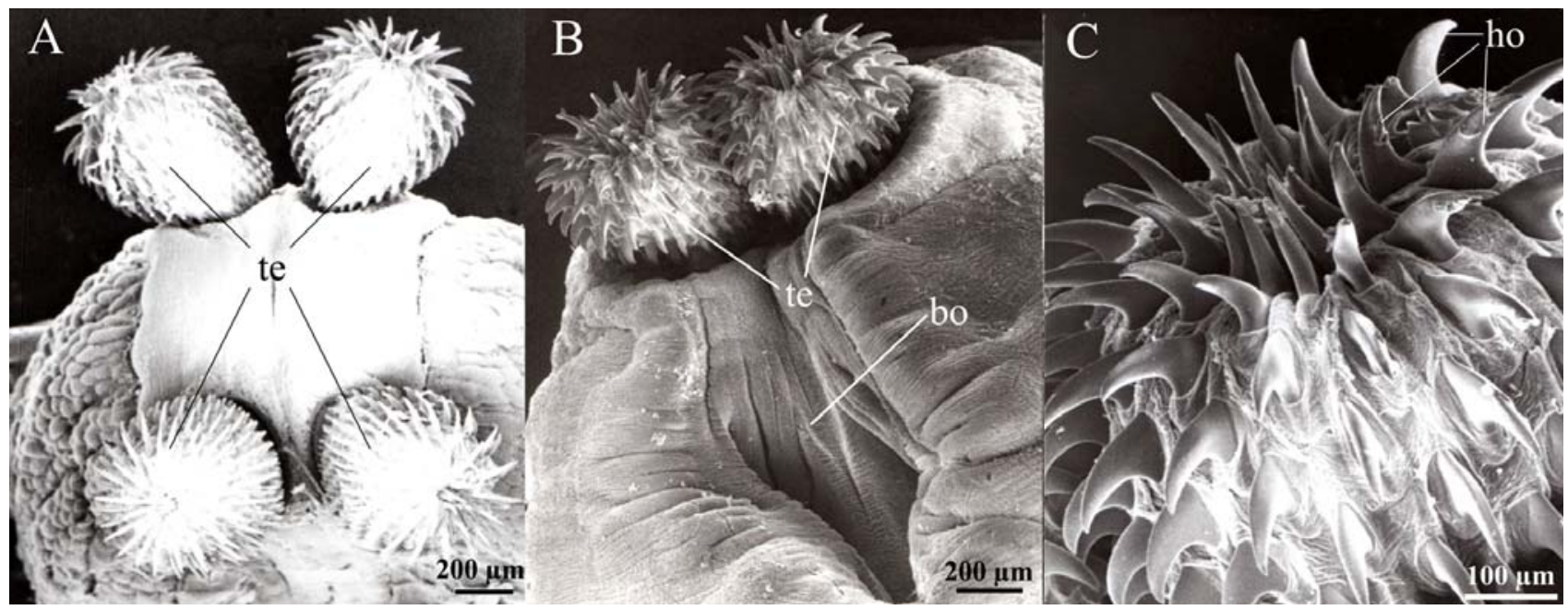

Figure 2

Hepatoxylon trichiuri from D. gigas. Scanning electron microscopy (SEM) of: A) tentacles, B) tentacles and bothria, C) tentacle armature. bo $=$ bothria, te $=$ tentacle, ho $=$ hook

Hepatoxylon trichiuri de D. gigas. Microscopía electrónica de barrido (MEB) de: A) tentáculos, B) tentáculos y botria, C) armadura tentacular. bo = botria, te = tentáculo, ho = gancho

(length $=0.09-0.12 \mathrm{~mm}$, basal $=0.06-0.08 \mathrm{~mm})($ Fig. 2c $)$. Hosts: Adults parasites of elasmobranchs (Schmidt 1986, George-Nascimento 1987, Palm 2004). Plerocercoids in a wide variety of fishes in Chile (George-Nascimento 1987). Distribution: Cosmopolitan (Schmidt 1986). Site: Mantle cavity, gonads and stomach. Deposition number of material: 10 specimens, MNHNCL 100001.

Remarks: The shape of the hooks (uncinate) and the tentacles armature are identical to specimens described by Palm (2004). Moreover, tentacles had 12-14 hook rows similar to those (12-15) described by Palm (2004).

Family: Tentaculariidae Poche, 1926

Tentacularia coryphaenae Bosc, 1797: (Abundance: 0.1; Prevalence: 5.6 \%) (Figs. 1b, 3)

Description: Measurements based on 20 specimens. Size range $8-15 \mathrm{~mm}$. Scolex elongated and craspedote (length = 5-10 mm, maximum width = 1-3 mm), (Fig. 1b). Four tentacles short, slender, armature homeoacanthous homeomorphous with uncinate hooks (Figs. 3a,b) (length $=0.030-0.033 \mathrm{~mm}$, basal $=0.020-0.026 \mathrm{~mm})$ and tridentate basal hooks (length $=0.015-0.026 \mathrm{~mm}$, basal $=0.008-0.010 \mathrm{~mm}$ ) (Fig. 3c). Four large and narrow bothria separated (length $=4.5-9 \mathrm{~mm}$ ), with hook-like microtriches along the bothrial margins present (Fig. 2d). Hosts: Larvae parasites of marine fishes and cephalopods (George-
Nascimento 1987, Hochberg 1990, Palm 2004). Adult parasites of elasmobranches (George-Nascimento 1987, Hochberg 1990, Palm 2004). Distribution: Cosmopolitan. Site: Mantle cavity and gonads. Deposition number of material: 10 specimens, MNHNCL 100002.

Remarks: The body measurements of T. coryphaenae were similar to specimens described by Shukhgalter \& Nigmatullin (2001). The length and basal lengths of metabasal and basal hooks were within the range of specimens measured by Shukhgalter \& Nigmatullin (2001). The shape of hook and tentacle armature was identical to specimens described by Palm (2000, 2004).

Order: Tetraphyllidea Carus, 1863

Plerocercoid larvae Tetraphyllidea: (Abundance: 9.1; Prevalence: 83.1\%) (Figs. 1c, 4, 5)

Description: Measurements based on 20 specimens. Size range 6-19 mm. Scolex short (length $=1-3 \mathrm{~mm}$, maximum width $=1-4 \mathrm{~mm}$ ), with apical sucker (Figs. 1c, 4a,b,c, $5 a)$. Four bothria large and sessile (length $=0.5-2 \mathrm{~mm}$ ) (Fig. 1c), with margins folded and curled (Figs. 4a). One accessory sucker on each bothria (Fig. 1c, 4b). The apical region of the scolex has a dome-shaped structure, and its internal tissue does not differ histologically from the rest of the scolex, except for the tissue surrounding the tip of similar to an accessory sucker composed by fibers of radial muscle and delimited by a thin muscular membrane (Fig. 


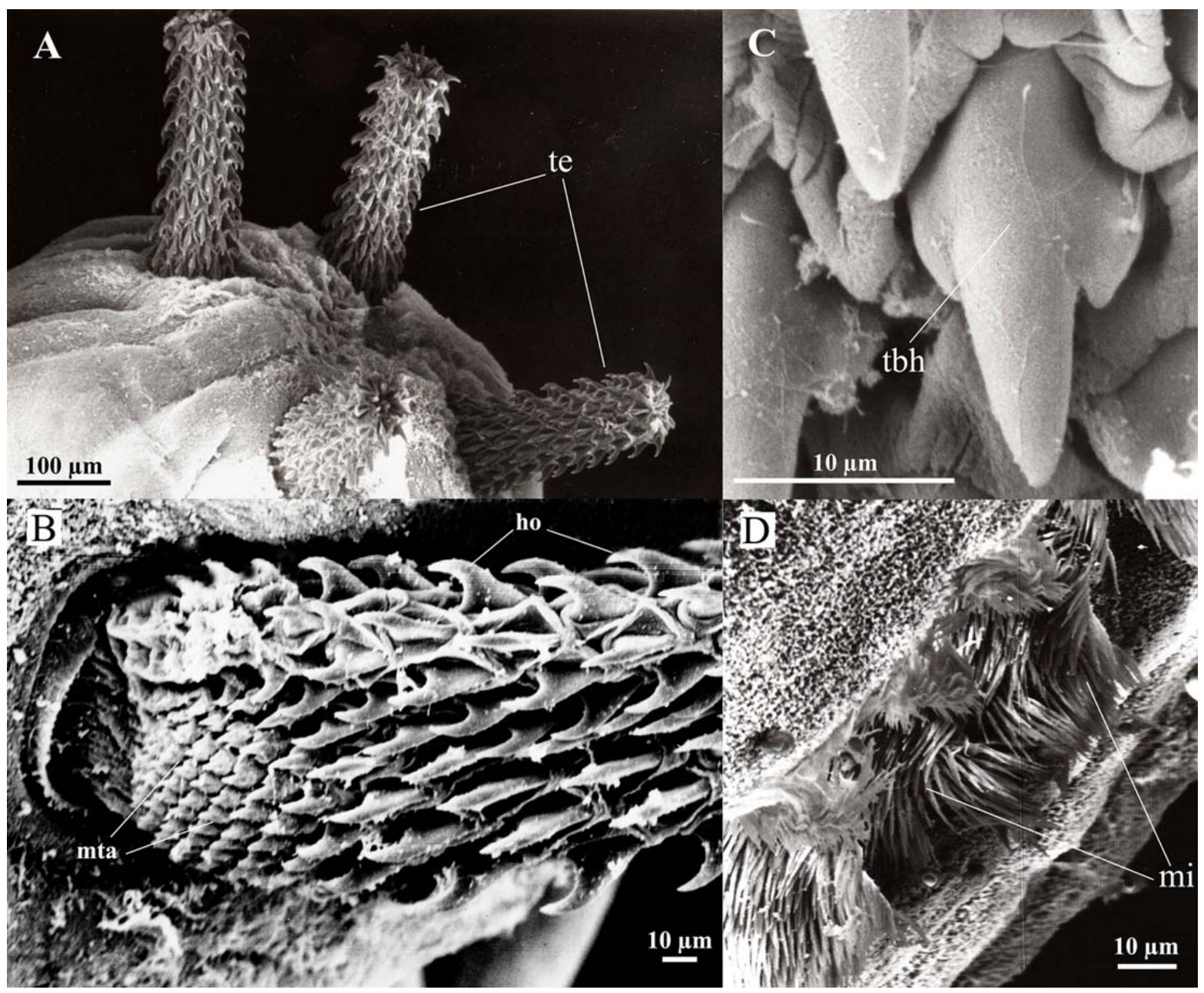

Figure 3

Tentacularia coryphaenae from D. gigas. SEM of: A) tentacles and bothria, B) tentacular armature, C) basal tentacular armature showing tridigitate basal hooks, D) hook-like microtriches along the bothrial margins. te = tentacle, $\mathrm{mi}=$ microtriches, $\mathbf{m t a}=$ metabasal tentacle armature, tbh $=$ tridentated basal hook

Tentacularia coryphaenae de D. gigas. MEB de: A) tentáculos y botrias, B) armadura tentacular, C) armadura de la base del tentáculo mostrando ganchos basales tridigitados, D) Microtricas en forma de ganchos a lo largo del margen botrial. te $=$ tentáculo, $\mathrm{mi}=$ microtricos, $\mathrm{mta}=$ armadura tentacular metabasal, $\mathrm{tbh}=$ gancho basal tridentado

5b). Hosts: Adults parasites of elasmobranches (Williams 1968, Hochberg 1990). Distribution: Pacific, Atlantic and Indian Oceans. Site: Stomach, caecum and intestine. Deposition number of material: 10 specimens, MNHNCL 100003.

Remarks: the presence of an apical sucker-like structure, accessory sucker on each bothria and the bothrial shape (folded and curled) resembles Phyllobothrium timidum Linton, 1922 described by Stunkard (1977). Morphometric measurements of larvae are similar to specimens described by Stunkard (1977) and Shukhgalter \& Nigmatullin (2001), what makes us believe this is a related species. However, molecular analysis suggests that previous reports of plerocercoids of Phyllobothrium spp. in squid may have been in error (Brickle et al. 2001).

Family: Phyllobothriidae Braun, 1900

Pelichnibothrium speciosum Monticelli, 1889 (Figs. 1d, 6)

Description: Measurements based on 10 cysts and 10 specimens. Size of cysts was 0.57-0.19 $\times 0.10-0.14 \mathrm{~mm}$. Larvae of small size (length $=0.12-0.15 \mathrm{~mm}$ width $=0.057$ - 

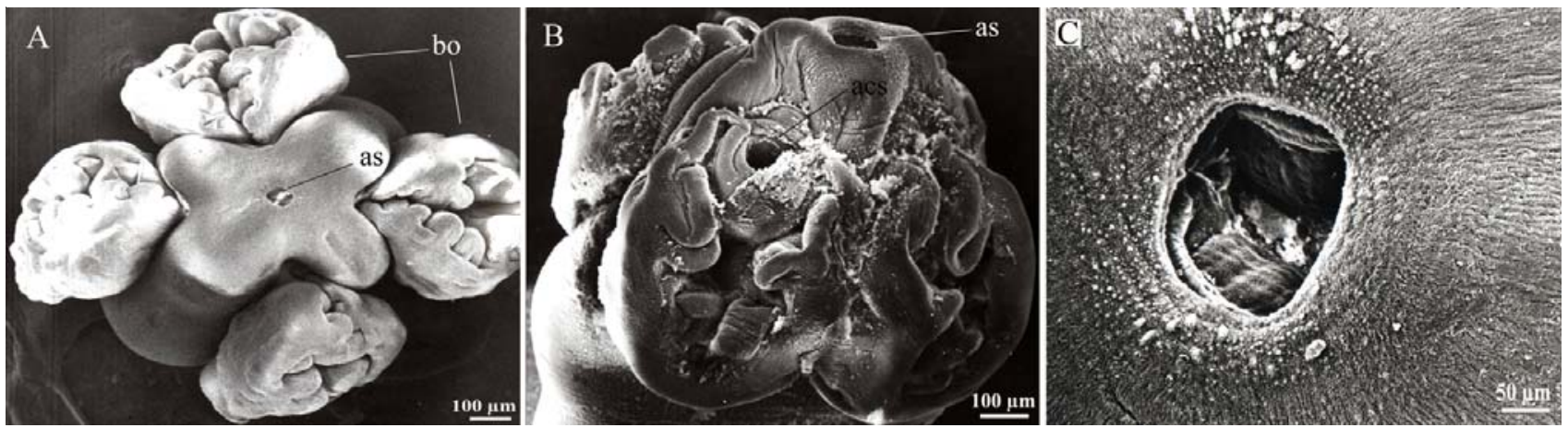

Figure 4

Tetraphyllidea plerocercoid from D. gigas. SEM of: A) bothria and apical sucker, B) bothrial folds, C) detail of apical sucker. bo $=$ bothria, as $=$ apical sucker, acs $=$ accessory sucker

Plerocercoide Tetraphyllidea de D. gigas. MEB de: A) botria y ventosa apical, B) pliegues botriales C) detalle de ventosa apical. bo = botria, as = ventosa apical, acs = ventosa accesoria
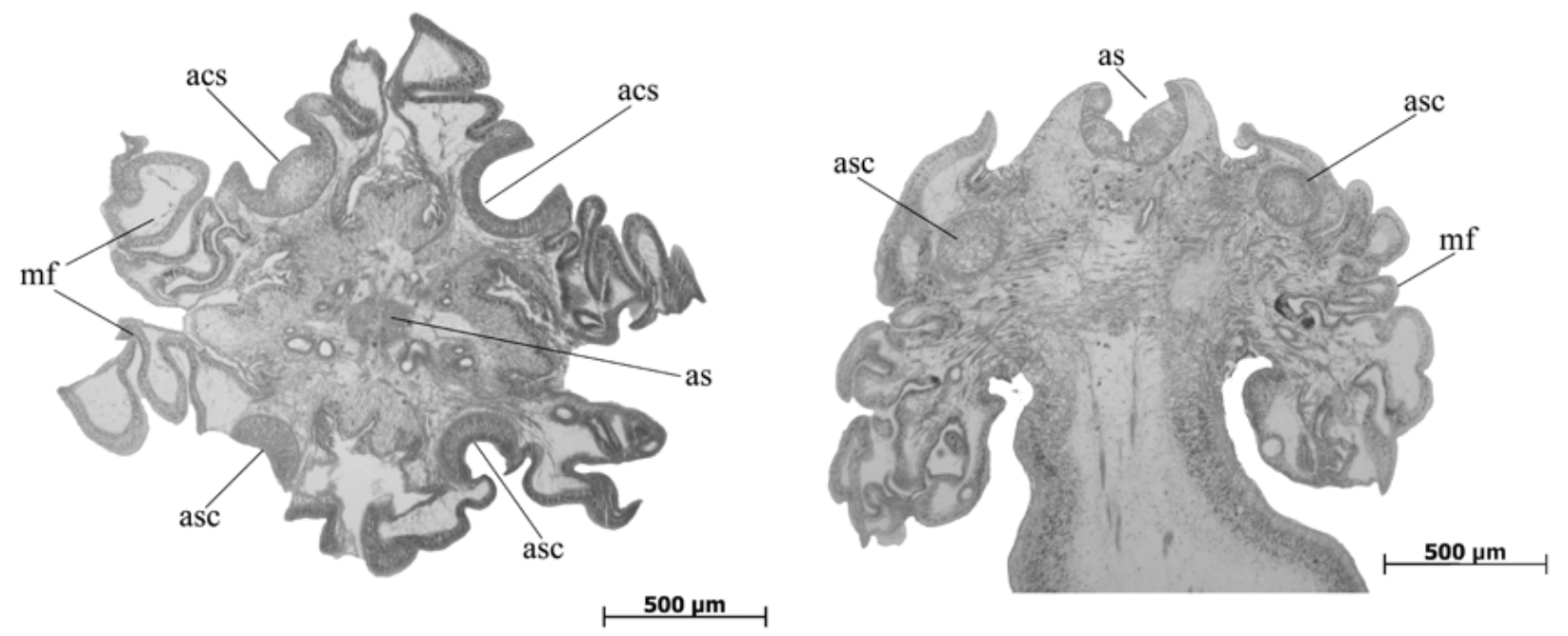

Figure 5

Histological sections of a Tetraphyllidea plerocercoid from D. gigas. A) Transverse section, B) Detail of apical region in longitudinal section. as = apical sucker, acs = accessory sucker, $\mathrm{mf}=$ margin fold. Stain: haematoxylin and eosin $(\mathrm{H} \& \mathrm{E})$

Corte histológico de plerocercoide Tetraphyllidea de D. gigas. A) Corte transversal, B) Detalle de la región apical en corte longitudinal. as = ventosa apical, acs = ventosa accesoria, $\mathrm{mf}=$ pliegue marginal. Tinción: hematoxilina y eosina $(\mathrm{H} \& \mathrm{E})$ 

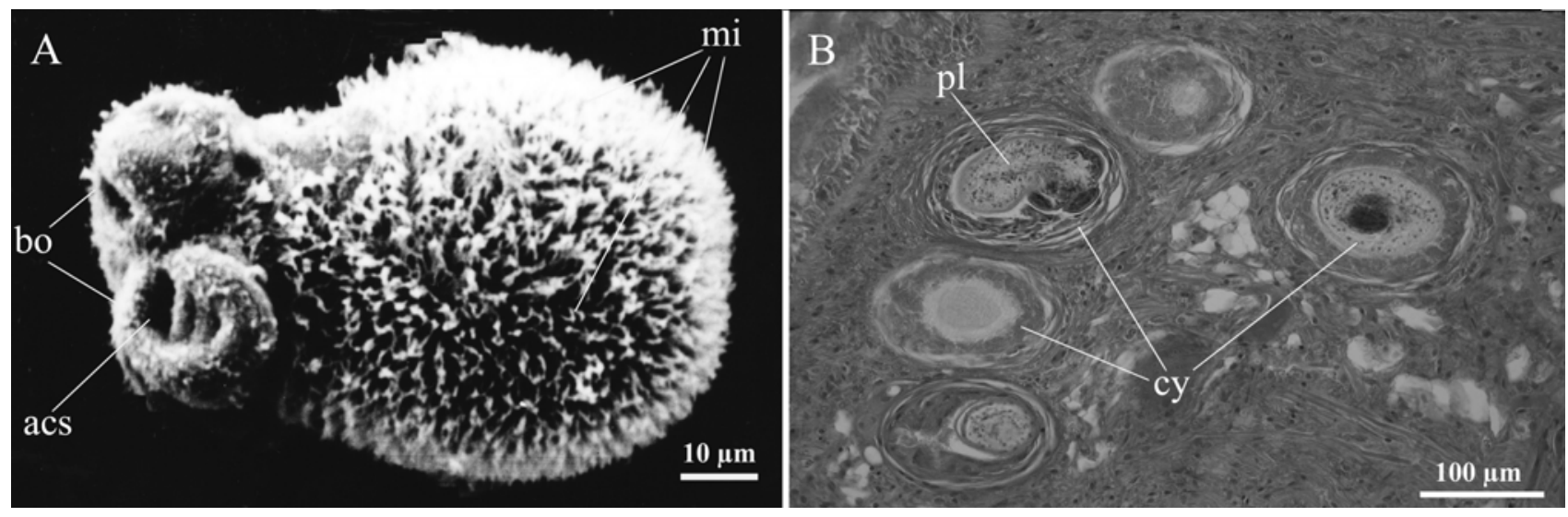

Figure 6

Pelichnibothrium speciosum from D. gigas. SEM of: A) larva, B) Histological section of rectum tissue of D. gigas showing cysts. Stain: haematoxylin and eosin $(\mathrm{H} \& \mathrm{E})$. bo = bothria, acs = accessory sucker, $\mathrm{mi}=$ microtriches, pl = plerocercoid, $\mathbf{c y}=$ cysts

Pelichnibothrium speciosum de D. gigas. MEB de: A) larva, B) preparación histológica de tejido del recto de D. gigas mostrando los quistes. Tinción: hematoxilina y eosina $(\mathrm{H} \& \mathrm{E})$. bo = botria, acs = ventosa accesoria, $\mathrm{mi}=$ microtricos,

$\mathrm{pl}=$ plerocercoide, $\mathrm{cy}=$ quistes

$0.085 \mathrm{~mm}$. Scolex short not clearly differentiated, with apical sucker (diameter $=0.028-0.040 \mathrm{~mm}$ ) (Fig. 1d). Four bothria sessile with free posterior ends (length $=0.037$ $0.040 \mathrm{~mm}$ ) (Fig. 6a), with an accessory sucker (Fig. 6a). Strobila short and covered with microtriches (Fig. 1d, 6a). In the same host individual different stages of development of this parasite species were found (Fig. 6b). Hosts: Larvae parasites of marine fishes and squids, adult parasites of Prionace glauca (Hochberg 1990, Scholtz et al. 1998). Distribution: Pacific, Atlantic and Indian Oceans. Site: intestine. Deposition number of material: rectum tissue with cysts, MNHNCL 100004.

Remarks: the presence of an apical sucker, an accessory sucker on each bothria and the body covered with microtriches resembles Pelichnibothrium speciosum described by Scholtz et al. (1998).

\section{Nematoda}

Family: Anisakidae Skrjabin \& Karokhin, 1945

Anisakis Type II: (Abundance: 0.52; Prevalence: 17.7\%) (Figs. 7a, 8a,b).

Description: Measurements based on 10 specimens. Size range $27-33 \mathrm{~mm}$, maximum body widths $0.63-0.74 \mathrm{~mm}$. Length from anterior end of body to nerve ring 0.35-0.43 $\mathrm{mm}$. Oesophagus length $1.82-2.89 \mathrm{~mm}$, maximum width $0.16-0.30 \mathrm{~mm}$. Size of ventriculus $0.53-0.65 \times 0.33-0.55$ $\mathrm{mm}$. Postanal tail round and without mucron or spine (length 0.17-0.32 mm) (Figs. 7a, 8b). Body surface totally striated (Fig. 7a). Mouth triangular anteroventrally (Fig. 8a). Boring tooth located ventral to the mouth. Excretory pore transverse slit situated between the ventrolateral lips (Fig. 8a). Postanal tail round, without terminal mucron. Hosts: Larvae parasites of marine fishes and cephalopods (George-Nascimento 1987, Hochberg 1990). Adult parasites of marine mammals (Hochberg 1990). Distribution: Cosmopolitan. Site: Gonads, stomach, caecum and intestine. Deposition number of material: 10 specimens, MNHNCL 100005.

Remarks: The ventriculus is relatively shorter and wider than in Anisakis Type I, with a ventriculus-intestinal junction characterized by shape slightly bilobed. The body measurement of Anisakis Type II was very similar to specimens of $A$. physeteris described by Shukhgalter \& Nigmatullin (2001). The absence of a tail mucron was the principal character that differentiated it from Anisakis Type I.

Anisakis Type I: (Abundance: 0.06; Prevalence: 6.5\%) (Fig. 7b, 8c,d)

Description: Measurements based on 10 specimens. Size range 25-35 mm, maximum body widths 0.62-0.75 mm. Length from anterior end of body to nerve ring 0.79-0.86 $\mathrm{mm}$. Oesophagus length $1.79-2.74 \mathrm{~mm}$, maximum width $0.18-0.25 \mathrm{~mm}$. Size of ventriculus $0.65-0.79 \times 0.21-039 \mathrm{~mm}$. Rounded tail (length $=0.20-0.30 \mathrm{~mm}$ ) with a mucron (length 
A

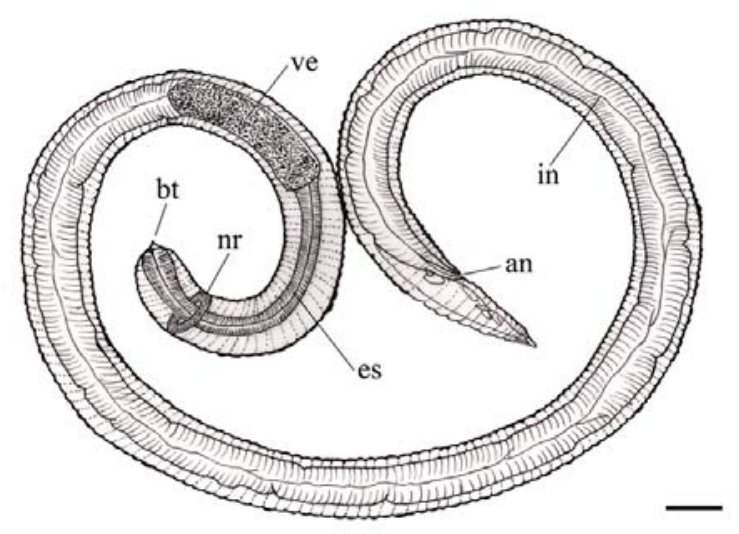

B

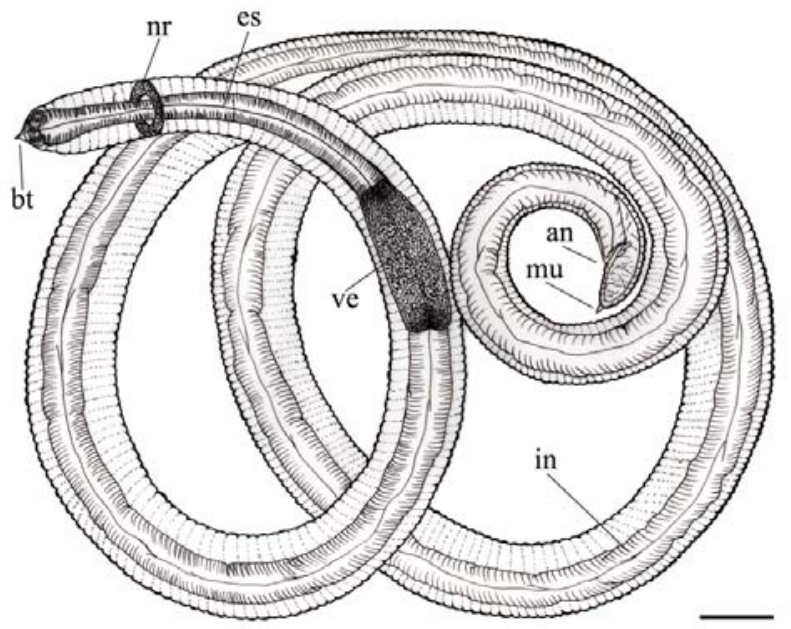

Figure 7

Nematode parasites of $D$. gigas. A) Anisakis Type II, scale bar $=0.7 \mathrm{~mm}$. B) Anisakis Type I, scale bar $=0.6 \mathrm{~mm}$. bt $=$ boring tooth, $\mathrm{nr}=$ nerve ring, es $=$ esophagus, ve $=$ ventriculus, in $=$ intestine, an $=$ anus, mu $=$ mucron

Nemátodos parásitos de D. gigas. A) Anisakis Tipo II, barra = 0,7 mm. B) Anisakis Tipo I, barra = 0,6 mm. bt = diente perforador, $\mathrm{nr}=$ anillo nervioso, es = esófago, ve = ventrículo, in = intestino, an = ano, $\mathrm{mu}=$ mucrón

$=0.02-0.05 \mathrm{~mm})($ Fig. $7 \mathrm{~b}, 8 \mathrm{~d})$. Body surface totally striated (Fig. 7b). Mouth rounded with dorsal and ventrolateral lips with papilla (Fig. 8c). Tooth located ventral to the mouth projecting anteroventrally. Excretory pore transverse slit situated between the ventrolateral lips, opens from a single excretory duct. Rectum opens at anus, with rectal glands. Postanal tail round, with a terminal mucron or spine. Hosts: Larvae parasites of marine fishes and cephalopods (George-Nascimento 1987, Hochberg 1990). Adult parasites of marine mammals (Hochberg 1990, Abollo et al. 1998). Distribution: Cosmopolitan. Site: Gonads, stomach, caecum and intestine. Deposition number of material: 1 specimen, MNHNCL 100006.

Remarks: The ventriculus is rather long and narrow with respect to Anisakis Type II, with a rounded posterior margin. The body measurements of Anisakis Type I was very similar to specimens of $A$. simplex described by Shukhgalter \& Nigmatullin (2001). The presence of a tail mucron was the principal character that differentiated it from Anisakis Type II.

\section{Discussion}

The present study is the first record of Dosidicus gigas parasites from south-central Chilean waters. We found six parasitic taxa all represented by larval stages, being Hepatoxylon trichiuri the first record for this host. Around nine taxa have been reported in $D$. gigas individuals smaller than $40 \mathrm{~cm}$ of ML (Shukhgalter \& Nigmatullin 2001), and five of them were found in this study (Pelichnibothrium speciosum, plerocercoids Tetraphyllidea, Tentacularia coryphaenae and Anisakis Type I and II), but in squids of larger body size. The parasite composition of $D$. gigas is very similar to those described for other ommastrephid squids (Naidenova et al. 1985, Bower et al. 1990, Bower \& Margolis 1991, Nigmatullin \& Shukhgalter 2001, Nigmatullin et al. $2005^{1}$ ) indicating a closeness in terms of ecological niches (Shukhgalter \& Nigmatullin 2001).

The genus Hepatoxylon is well known and includes two species, $H$. trichiuri and $H$. megacephalum (Palm 2004). The genus is distributed worldwide from the tropical to the boreal region, occurring as adults in pelagic sharks, with the plerocercoids infesting teleosts and sharks (Schmidt 1986, Palm 2004). Larval stage of this parasite has been reported in other four squid species, Architeuthis dux, Illex argentinus, Sthenoteuthis pteropus and Todarodes angolensis, but in the Atlantic Ocean (Hochberg 1990, Palm 2004). However, it has not been reported in Pacific Ocean squids. Therefore, this would be the first reported of $H$. trichiuri infecting squids in the Pacific Ocean.

The genus Tentacularia is well known and comprises only a single species, $T$. coryphaenae (Palm 2004). This genus is distributed worldwide in tropical and subtropical 


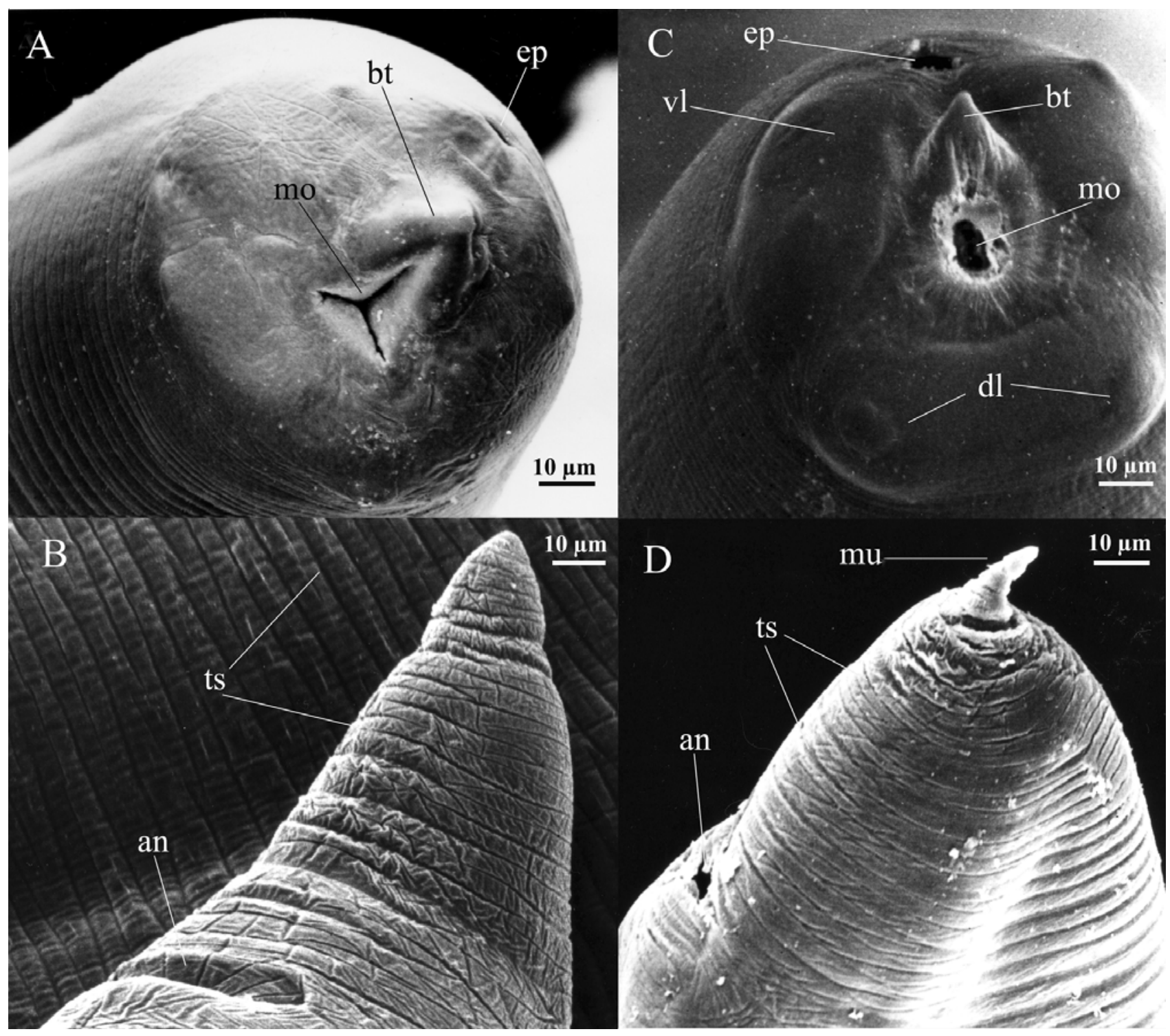

Figure 8

Anisakis from D. gigas. SEM of: A) head with mouth triangular and four papilla of $A$. Type II, B) postanal rounded tail of $A$. Type II C) head showing mouth rounded with dorsal and ventrolateral lips with papilla of $A$. Type I,

D) postanal rounded tail with terminal mucron of $A$. Type $I$ bt $=$ boring tooth, an $=$ anus, mu $=$ mucron, ep $=$ excretory pore, mo $=$ mouth, $\mathrm{vl}=$ ventral lip, $\mathrm{dl}=$ dorsal lip, $\mathrm{ts}=$ transverse striation

Anisakis de D. gigas. MEB de: A) cabeza con boca triangular de A. Tipo II, B) cola postanal redondeada de A. Tipo II, C) cabeza mostrando la boca redondeada con labios dorsal y ventrolaterales con papilas de $A$. Tipo I, D) cola postanal redondeada, con un mucrón terminal de $A$. Tipo I bt = diente perforador, an = ano, mu = mucrón, ep = poro excretor, 
seas, inhabiting migratory scombrids and larger pelagic predatory fish as second intermediate hosts and carcharhinid sharks as final hosts (George-Nascimento 1987, Hochberg 1990, Palm 2004). Palm (2000) studied T. coryphaenae from fish hosts with SEM, recording the tentacular armature and microtriches along the bothrial margins. A similar larval cestode with the same taxonomic characteristics was recorded in this study from D. gigas, and was identified as T. coryphaenae. This taxon has also been registered from 19 other squid species (Hochberg 1990, Palm 2004).

The Tetraphyllidean plerocercoid was difficult to identify to the genus or species level, since only larval specimens were available, but it is very similar to Phyllobothrium genus. Following the approach of Caira et al. (1999) in the description of larval cestodes, in stained specimens it is possible to distinguish a structure similar to an apical organ, with a discrete boundary between this structure and the tissue of the scolex proper. Furthermore, the apical organ has the same shape and tissue than the accessory suckers, so it could be a Phyllobothrium plerocercoid. However, molecular analysis is necessary to confirm this. These larvae are present in many species of cephalopods and fishes and the adults are found in several sharks and rays (Williams 1968, Hochberg 1990).

Pelichnibothrium speciosum is the only species of the genus (Scholtz et al. 1998). Larvae of this species parasitize 12 cephalopod species and some fishes (Hochberg 1990), and adults of $P$. speciosum seem to be specific parasites of Prionace glauca (Scholtz et al. 1998). The geographical distribution of $P$. speciosum is fairly extensive and probably cosmopolitan, as records include the North Atlantic Ocean, inclusive of the Mediterranean Sea, the Indian Ocean and the Pacific Ocean (Scholtz et al. 1998, Shukhgalter \& Nigmatullin 2001).

A low prevalence and abundance of Anisakis Type I rather than Anisakis Type II was found in this study, a similar situation has been reported from Peru (Shukhgalter \& Nigmatullin 2001). Larval Anisakis species have been differentiated morphologically by the shape and size of the ventriculus and the presenceabsence of tail mucron (see Hochberg 1990, Shukhgalter \& Nigmatullin 2001). Anisakis Type I and II showed differences in the ventriculus size and the ventriculusintestinal junction were characterized by the shape rounded and slightly bilobed in both Anisakis respectively. Furthermore, the shape of the mouth and the tail with the presence-absence of tail mucron too distinguished between Anisakis Type I and II. However, the molecular analysis indicates that the genetic markers are very useful to identify larval stages of Anisakis spp., in the cases that the morphological characters are not sufficient at the genus level or species (Mattiucci et al. 2005, 2008) or when sibling species exist like the morphotypes Type I that involve at least three biological species (Anisakis simplex, A. pegreffii and A. typical), and the morphotype Type II (A. physeteris, A. brevispiculata and A. paggiae), in the North Atlantic (Mattiucci et al. 2008). In fact the molecular analysis of Anisakis Type I and II infecting the fishes Merluccius gayi and Hoplostethus atlanticus, caught off the Chilean coast, correspond to Anisakis pegreffii and A. paggiae, respectively (Mattiucci et al. 2008²). These records make us think that Anisakis spp. infecting D. gigas from Chile could be one of these species.

Some metazoan parasites have been used to monitor populations of different cephalopod species from the North Pacific, North Atlantic and the Mediterranean Seas (Bower \& Margolis 1991, Pascual \& Hochberg 1996). Hepatoxylon trichiuri appears to be absent from D. gigas from Central and Eastern Pacific (Bower et al. 1990, Shukhgalter \& Nigmatullin 2001). However, this parasite species is common in Chilean waters, suggesting that it could be a good indicator (biological tag) of a relatively low migration of D. gigas from Perú to Chile. Keyl et al. (2008) suggest that the Nazca Ridge possibly acts as a barrier for smaller $D$. gigas, preventing them from migrating to cooler water masses in the south in years of low abundance. However, the genetic data show a great genetic flow between these areas (Sandoval-Castellanos et al. 2007), and the parasite could help to reveal the migration paths in the Humboldt Current System.

Comparing with literature, differences in composition of parasitic fauna can be the result of geographic variations in relation to trophic habits. Nigmatullin et al. (2001, 2005 ${ }^{1}$ ) suggest that these parasites are transmitted by planktonic crustaceans and small fishes like myctophids from the diet of Ommastrephid squids. In Chile D. gigas feed on mycthophids, predatory fishes, euphausiids and cephalopods (Ibáñez et al. 2008), which are responsible for the parasitic fauna in these latitudes.

The occurrence of parasites in many species of cephalopods is common, and these molluscs play an

\footnotetext{
${ }^{1}$ Mattiucci S, M Paoletti, S Damiano, SC Webb, M GeorgeNascimento, B Berland, A Garcia \& G Nascetti. 2008. New genetic and ecological data on Anisakis spp. (Nematoda: Anisakidae), with evidence for new sibling species. XXV Congress of the Società Italiana di Parassitologia, Pisa 18-21 giugno, 2008. Parassitologia 50(Suppl. 1): 20. [Abstract]
} 
important role as a trophic bridge for parasite flow in marine ecosystems (Abollo et al. 1998). We suggest that D. gigas might be a parathenic host for cestodes and nematodes in Chilean waters, because this squid is prey of sperm whales (Clarke \& Paliza 2000), sharks (Reyes 2005, Pardo-Gandarillas et al. 2007), swordfish (Ibáñez et al. 2004, Castillo et al. 2007) and sea lions (GeorgeNascimento et al. 1985), predators that are the definitive host for the parasites recorded in this study.

For confirmation of the taxonomic status level of larval stages of the parasites we suggest the use of molecular tools.

\section{Acknowledgments}

We wish to thank Harry Palm very much for his great help in this study. We thank Chingis Nigmatullin for showing us «life» where the cysts of Pelichnibothrium are, sampling with two of us in Coquimbo, for his help in the identification of some parasites, and also for reviewing and considerable improving this manuscript. Our gratitude to three anonymous reviewers for most valuable comments on the manuscript.

\section{Literature cited}

Abollo E, C Gestal, A López, AF González, A Guerra \& S Pascual. 1998. Squid as trophic bridges for parasites flow within marine ecosystems: the case of Anisakis simplex (Nematoda: Anisakidae), or when the wrong way can be right. South African Journal of Marine Science 20: 223232.

Bower SM \& L Margolis. 1991. Potential use of helminth parasites in stock identification of flying squid, Ommastrephes bartrami, in the North Pacific waters. Canadian Journal of Zoology 69: 1124-1126.

Bower SM, L Margolis \& DTC Yang. 1990. A preliminary investigation of the helminth parasites of flying squid, (Ommastrephes bartrami), in Northeastern Pacific waters and comparison with other parasite surveys of Ommastrephidae, Canadian Technical Report of Fisheries and Aquatic Sciences 1750: 1-19.

Brickle P, PD Olson, DTJ Littlewood, A Bishop \& AI Arkhipkin. 2001. Parasites of Loligo gahi from waters off the Falkland Islands, with a phylogenetically based identification of their cestode larvae. Canadian Journal of Zoology 79: 2289-2296.

Caira JN, K Jensen \& CJ Healy. 1999. On the phylogenetic relationships among tetraphyllidean, lecanicephalidean and diphyllidean tapeworm genera. Systematic Parasitology 42: 77-151.

Castillo K, CM Ibáñez, J Chong \& C González. 2007. Dieta del pez espada Xiphias gladius Linnaeus, 1758 en distintas zonas de pesca frente a Chile central durante el otoño de
2004. Revista de Biología Marina y Oceanografía 42(2): 149-156.

Clarke R \& O Paliza. 2000. The Humboldt Current squid Dosidicus gigas (Orbigny, 1835). Revista de Biología Marina y Oceanografía 35: 1-39.

Fernández F \& JA Vásquez. 1995. La jibia gigante Dosidicus gigas (Orbigny, 1835) en Chile: análisis de una pesquería efímera. Estudios Oceanológicos 14: 17-21.

George-Nascimento M. 1987. Ecological helminthology of wildlife animal hosts from South America: a literature review and a search for patterns in marine food webs. Revista Chilena de Historia Natural 60: 181-202.

George-Nascimento M, R Bustamante \& C Oyarzún. 1985. Feeding ecology of the South American sea lion Otaria flavescens: food contents and food selectivity. Marine Ecology Progress Series 21: 135-143.

Gestal C, E Abollo, C Arias \& S Pascual. 1998a. Estudio al M.E.B. de larvas plerocercoides de Phyllobothrium sp. (Tetraphyllidea, Phyllobothriidae) y Nybelinia lingualis (Trypanorhyncha, Tentaculariidae), cestodos parásitos de Octopus vulgaris (Mollusca, Cephalopoda) en la Ría de Vigo. Iberus 16: 125-132.

Gestal C, E Abollo, C Arias \& S Pascual. 1998b. Larval nematodes (Spiruroidea: Cystidicolidae) in Octopus vulgaris (Mollusca: Cephalopoda: Octopodidae) from the Northeastern Atlantic Ocean. Journal of Parasitology 85(3): 508-511.

Hochberg FG. 1990. Diseases of Mollusca: Cephalopoda En: Kinne O (ed). Diseases of marine animals, Vol. III: Introduction, Cephalopoda, Annelida, Crustacea, Chaetognatha, Echinodermata and Urochordata, pp. 47227. Biologische Anstalt Helgoland, Hamburg.

Ibáñez CM, C González \& L Cubillos. 2004. Dieta del pez espada Xiphias gladius Linnaeus, 1758, en aguas oceánicas de Chile central en invierno de 2003. Investigaciones Marinas 32(2): 113-120.

Ibáñez CM, H Arancibia \& LA Cubillos. 2008. Biases in determining the diet of jumbo squid Dosidicus gigas (D' Orbigny 1835) (Cephalopoda: Ommastrephidae) off southern-central Chile $\left(34^{\circ} \mathrm{S}-40^{\circ} \mathrm{S}\right)$. Helgoland Marine Research 62(4): 331-338.

Keyl F, J Argüelles, L Mariátegui, R Tafur, M Wolff \& C Yamashiro. 2008. A hypothesis on range expansion and spatio-temporal shifts in size-at-maturity of jumbo squid (Dosidicus gigas) in the Eastern Pacific Ocean. CalCOFI Report 49: 119-128.

Margolis L, GW Esch, JC Holmes, AM Kuris \& GA Schad. 1982. The use of ecological terms in parasitology (Report of an ad hoc committee of the American Society of Parasitologists). Journal of Parasitology 68: 131-133.

Mattiucci S, G Nascetti, M Dailey, SC Webb, $N$ Barros, $R$ Cianchi \& L Bullini. 2005. Evidence for a new species of Anisakis Dujardin, 1845: morphological description and genetic relationships between congeners (Nematoda: Anisakidae). Systematic Parasitology 61: 157-171. 
Mattiucci S, V Farina, N Campbell, K MacKenzie, $\mathbf{P}$ Ramos, AL Pinto, P Abaunza \& G Nascetti. 2008. Anisakis spp. larvae (Nematoda: Anisakidae) from Atlantic horse mackerel: Their genetic identification and use as biological tags for host stock characterization. Fisheries Research 89: 146-151.

Naidenova NN, ChM Nigmatullin \& AV Gaevskaya. 1985. The helminth fauna and host-parasite relations of squid Sthenoteuthis oualaniensis (Lesson) (Cephalopoda, Ommastrephidae) in the Indian Ocean and the Red Sea. In: Harris WJ Jr (ed). Parasitology and pathology of marine organisms of the world ocean. NMFS NOAA Technical Report 25: 113-116.

Nigmatullin ChM \& OA Shukhgalter. 2001. The macroecosystem variations of helminth fauna in Ommastrephid squid Sthenoteuthis oualaniensis from Indian Ocean and East Tropical Pacific. In: ICES Annual Science Conference, Response of cephalopod populations and fisheries to changing of environment and ecosystems, 26- 29 september, Oslo. ICES CM 2001/K:21: 1-11.

Nigmatullin ChM, KN Nesis \& AI Arkhipkin. 2001. A review of the biology of the jumbo squid Dosidicus gigas (Cephalopoda: Ommastrephidae). Fisheries Research 54: 9-19.

Palm HW. 2000. Trypanorhynch cestodes from Indonesian coastal waters (East Indian Ocean). Folia Parasitologica 47: 123-134.

Palm HW. 2004. The Trypanorhyncha Diesing, 1863, 710 pp. PKSPL-IPB Press, Bogor.

Pardo-Gandarillas MC, F Garcías \& M GeorgeNascimento. 2004. La dieta y fauna de endoparásitos del pejesapo Gobiesox marmoratus Jenyns, 1842 (Pisces: Gobiesocidae) en el litoral central de Chile están conectadas pero no correlacionadas. Revista Chilena de Historia Natural 77(4): 627-637.

Pardo-Gandarillas MC, F Duarte, J Chong \& CM Ibáñez. 2007. Dieta de tiburones juveniles Prionace glauca (Linnaeus, 1758) (Carcharhiniformes: Carcharhinidae) en la zona litoral centro-sur de Chile. Revista de Biología Marina y Oceanografía 42(3): 365-369.

Pascual S \& FG Hochberg. 1996. Marine parasites as biological tags of cephalopod hosts. Parasitology Today 12(8): 324-327.

Pascual S, AF González, C Arias \& A Guerra. 1999. Larval Anisakis simplex B (Nematoda: Ascridoidea) of short-finned squid (Cephalopoda: Ommastrephidae) in north-west Spain. Journal of the Marine Biological Association of the United Kingdom 79: 65-72.

Pascual S, AF González \& A Guerra. 2007. Parasites and cephalopod fisheries uncertainty: towards a waterfall understanding. Reviews in Fish Biology and Fisheries 17: 139-144.
Reyes PR. 2005. Antecedentes preliminares sobre la alimentación del cazón Galeorhinus galeus (Linnaeus, 1758) (Carcharhiniformes: Triakidae) en la zona centrosur de Chile. Revista de Biología Marina y Oceanografía 40(1): 83-86.

Sandoval-Castellanos E, M Uribe-Alcocer \& P DíazJaimes. 2007. Population genetic structure of jumbo squid (Dosidicus gigas) evaluated by RAPD analysis. Fisheries Research 83: 113-118.

Schmidt GD. 1986. Handbook of tapeworm identification, 675 pp. CRC Press, Boca Raton.

Schmiede P \& E Acuña. 1992. Regreso de las jibias (Dosidicus gigas) a Coquimbo. Revista Chilena de Historia Natural 65: 389-390.

Scholtz T, L Euzet \& F Moravec. 1998. Taxonomic status of Pelichnibothrium speciosum Monticelli, 1889 (Cestoda: Tetraphyllidea), a mysterious parasite of Alepisaurus ferox Lowe (Teleostei: Alepisauridae) and Prionace glauca (L.) (Euselachii: Carcharinidae). Systematic Parasitology 41: 1-8.

Shaw BL \& HI Battle. 1957. The gross microscopic anatomy of the digestive tract of the oyster Crassostrea virginica (Gmelin). Canadian Journal of Zoology 35: 325-347.

Shukhgalter OA \& ChM Nigmatullin. 2001. Parasitic helminths of the jumbo squid Dosidicus gigas (Cephalopoda: Ommastrephidae) in open waters of the central east Pacific. Fisheries Research 54: 95-110.

Stunkard HW. 1977. Studies on Tetraphyllidean and Tetrarhynchidean metacestodes from squids taken on the New England coast. The Biological Bulletin 153: 387-412.

Turner RD \& PJ Boyle. 1975. Studies of bivalve larvae using the scanning electron microscope and critical point drying. Bulletin of the American Malacological Union 1975: 5965.

Wilhelm O. 1954. Algunas observaciones acerca de las mortandades de jibias (Dosidicus gigas D’Orb), en el litoral de Concepción. Revista de Biología Marina 4: 196-201.

Williams HH. 1968. The taxonomy, ecology and hostspecificity of some Phyllobothriidae (Cestoda: Tetraphyllidea), a critical revision of Phyllobothrium Beneden, 1849 and comments on some allied genera. Philosophical Transactions of the Royal Society of London Series B. Biological Sciences 253: 231-307.

Yamaguti S. 1961. Systema Helminthum. The Nematodes of vertebrates. Volume III, 679 pp. Interscience Publishers, New York. 